\title{
Application of Recent Biotechnologies to Prunus Tree Crop Genetic Improvement ${ }^{1,2}$
}

\author{
P. Martínez-Gómez ${ }^{3}$, R. Sánchez-Pérez ${ }^{3}$, M. Rubio ${ }^{3}$, F. Dicenta ${ }^{3}$, \\ T.M. Gradziel ${ }^{4}$ and G.O. Sozzi ${ }^{5}$ \\ ${ }^{3}$ Departamento de Mejora Vegetal, CEBAS-CSIC. Campus Universitario de Espinardo, E-30100 Murcia, Spain. \\ ${ }^{4}$ Department of Pomology, University of California , Davis. One Shields Avenue, Davis, CA 95616, USA. \\ ${ }^{5}$ Cátedra de Fruticultura, Facultad de Agronomía, Universidad de Buenos Aires, Avda. San Martín 4453, C1417DSE \\ Buenos Aires, Argentina. Consejo Nacional de Investigaciones Científicas y Técnicas, Argentina.
}

\begin{abstract}
P. Martínez-Gómez, R. Sánchez-Pérez, M. Rubio, F. Dicenta, T.M. Gradziel and G.O. Sozzi. Application of Recent Biotechnologies to Prunus Tree Crop Genetic Improvement. Promising tools for Prunus breeding include germplasm introgression, molecular marker development and improved propagation and gene transfer techniques. In germplasm introgression, the introduction of genes from related Prunus species conferring agronomically valuable traits such as self-compatibility, improved growth habit, drought resistance, and higher kernel quality are being pursued. The analyses of twin seeds (two embryos within the same seedcoat) are facilitating genetic and cytogenetic studies. Useful propagation methods include in-vitro techniques for the evaluation of plant material, and invivo micrograft techniques that allow the early propagation of high-risk genotypes. In addition, plant growth under controlled environments, including the induction of an artificial rest period using cold chambers, provides a useful strategy for obtaining vigorously growing plants all the year round. Molecular markers have also become an essential tool in Prunus genetic improvement studies. Different types of molecular markers, including isoenzymes, RFLPs, RAPDs, AFLPs and SSRs, have been employed for the genetic characterization of germplasm, the establishment of genetic relationships between cultivars and species, and the construction of genetic maps. Methodologies for the analysis of marker-assisted selection include the use of mapping populations segregating for desired characters and bulk segregant analysis. Genetic engineering offers a resolution to problems encountered by traditional Prunus breeding programs including long juvenility period and large space requirements for breeding populations. A number of genetically modified Prunus cultivars have been obtained using different gene transfer methods. Additional research work is still required to fully develop the next generation of gene vectors and transgenic plants.
\end{abstract}

Key words: Almond, apricot, cherry, gene transfer, germplasm, molecular markers, peach, plum, propagation techniques.

\footnotetext{
Received on 21 March 2005; Accepted on 10 May 2005

${ }^{1}$ This review is dedicated to Dr. Dale E. Kester, who died November 21, 2003, at Davis (California). Dr. Dale E. Kester was Professor of Pomology emeritus at the University of California, Davis. He taught courses in Plant Propagation and Pomology for four decades and authored over 100 research and technical publications. He always demonstrated great enthusiasm for the incorporation of new technologies to Prunus breeding and is remembered as a dedicated, hardworking scientist, teacher and human being whose guidance and insight are missed.

${ }^{2}$ This work was partially supported by the Universidad de Buenos Aires (Code G 099), and the Agencia Nacional de Promoción Científica y Tecnológica, Argentina.

${ }^{5}$ Correspondence to G.O. Sozzi: gsozzi@agro.uba.ar
} 


\section{INTRODUCTION}

The Prunoideae, a subfamily of Rosaceae, includes several species producing edible drupes with economic importance. In 2002, worldwide annual production of Prunoideae exceeded 30 million metric tons, including almost 13.9 million tons of nectarines and peaches (Prunus persica (L.) Batsch), 1.8 million tons of almonds (Prunus amygdalus Batsch $=$ Prunus dulcis (Miller) D.A. Webb), 2.7 million tons of apricots (Prunus armeniaca $\mathrm{L}$.), 1.8 million tons of sweet cherries (Prunus avium L.), 0.9 million tons of sour cherries (Prunus cerasus L.) and 9.3 million tons of plums (Prunus domestica L.) (FAO, 2003). Prunus species are characterized by developing only one ovary in which two ovules typically form, one of which degenerates soon after anthesis. The fruit is a drupe where the mature, stony endocarp together with the seed forms a propagation unit comparable to a botanical seed surrounded by its protective testa.

Breeding practices in Prunus face unique challenges resulting from the narrow genetic background of commercial cultivars (Scorza et al., 1985), a long juvenile period combined with large plant size, and differences in trait expression between juvenile and mature trees (Baird et al., 1996). In the last decade, many techniques such as in vitro culture and the use of molecular markers have become available for Prunus crop breeding. These methods are now moving from laboratory evaluation to field application. Concurrently, different aspects of the emerging biotechnologies, including markerassisted selection and genome mapping, as well as the impact of altered gene expression on Prunus sp., have now been extensively reviewed (Mehlenbacher, 1995; Baird et al., 1996; Luby and Shaw, 2001; Scorza, 2001).

This article offers an overview of the current approaches being developed to optimize breeding efficiency by improving both germplasm in general and important horticultural traits in particular. These approaches include germplasm introgression, propagation techniques, use of molecular markers, and gene transfer technologies.

\section{GERMPLASM IMPROVEMENT}

Related Prunus species. The available germplasm in Prunus is diverse and the origin and dissemination for several species have been extensively reviewed (Kester et al., 1991; Faust and Timon, 1995; Faust and Surányi, 1997, 1999; Faust et al., 1998). Considerable genetic variation for these species still exists, mainly in the mountainous areas of Central Asia from the Tian Shan region in China to Kurdistan, including Turkestan, Afghanistan, Iran and Iraq. However, in cultivated germplasm, a limited gene pool restricts production to specific areas and conditions (Scorza et al., 1985). The introduction of genes from related species through interspecific hybridization has been used in several breeding programs throughout the world primarily to develop better-adapted rootstocks.

Rootstock breeding programs using interspecific hybridization have introduced useful traits including size control, adaptation to the new environments and pest resistance. Interspecific crosses between Prunus species (primarily peach $\mathrm{x}$ almond, but also $P$. webbii $\mathrm{x}$ peach, and others) have been widely utilized in almond rootstock breeding in France (Bernhard, 1949), USA (Kester and Hansen, 1966), Spain (Felipe, 1975), and Yugoslavia (Vlasic, 1977).

The introgression of almond germplasm from related species, including $P$. webbii (Spach) Vieh., $P$. argentea Lam, $P$. persica, $P$. bucharica Korshinsky, P. mira Koehne and P. scoparia Batal. has allowed transfer of several useful traits including self-compatibility, fungal and pest resistance, and frost and drought tolerance (Grasselly, 1976; Kester et al., 1991; Kester and Gradziel, 1996; Gradziel et al., 2001a). P. davidiana (Carr.) Frans. has recently been reported to be a source of plum pox virus (PPV) resistance for peach (Pascal et al., 2001), while the introgression of Prunus mandshurica (Maxim.) Koehne genes to apricot have improved frost resistance in Eastern 
and Central European programs (Paunovic, 1988).

In almond, the absence of extensive crossing barriers in either the initial hybridization or subsequent backcrosses demonstrates a direct accessibility of this rich germplasm to breeding (Browicz and Zohary, 1996; Gradziel et al., 2001a). Potential barriers to successful interspecific gene introgression include male sterility, poor germplasm maintenance, and problems associated with character quality (Smith, 2002). The encouraging performance of interspecific hybrids and backcrosses to date, support continuing opportunities for transferring useful traits, including self-compatibility, resistance to important pests and diseases, improvement of seed oil quality, tolerance to aberrant environments, and modified tree architecture and bearing habit (Gradziel et al., 2001a) (Table 1). International collaborations have further allowed a more thorough evaluation of wild and related germplasm prior to extensive gene introgression (Esquinas-Alcazar, 1993), and have helped minimize breeding obstacles imposed by quarantine restrictions (Mora-Aguilera et al., 1998).

Table 1. Prunus species with reported value for the genetic improvement of peach and almond.

Cuadro 1. Especies de Prunus descritas de gran valor para el mejoramiento genético de duraznero y almendro.

\begin{tabular}{lll}
\hline Section & Species & Use in peach and almond breeding ${ }^{1}$ \\
\hline Amygdalus Spach. & P. persica (L.) Batsch. & Self-compatibility and pest and disease resistance in almond \\
& P. davidiana (Carr.) Franch. & Disease resistance in peach and self-compatibility in almond \\
& P. mira Koehne. & Disease resistance in peach and self-compatibility in almond \\
& P. dulcis (Mill.) D.A. Webb & Pest and disease resistance in peach \\
& P. argentea Lam. & Self-compatibility and frost resistance in almond \\
& P. bucharica Korschinsky & Self-compatibility, growth habit and frost resistance in almond \\
& P. kuramica Korschinsky & Self-compatibility and disease resistance in almond \\
& P. webbii (Spach) Vieh. & Self-compatibility and growth habit in almond \\
Chameamygdalus Spach. & Petunikowii Lits. & Pest and disease resistance in almond \\
& P. tangutica Batal. & Pest and disease resistance in almond \\
Spartioides Spach. & P. scoparia Batal. & Self-compatibility and drought resistance in almond \\
Leptopus Spach. & P. pedunculata Pall. & Pest and disease resistance in almond \\
\hline
\end{tabular}

'Hesse, 1975; Grasselly, 1976; Denisov, 1988; Kester et al, 1991; Kester and Gradziel, 1996; Scorza and Sherman, 1996; Gradziel et al., 2001a, 2002.

Multiple embryos. Twin seeds (multiple embryos within the same seed coat) occur spontaneously in several Prunus species including peach and almond (Hesse, 1971; Kester and Gradziel, 1996). The occurrence of these multiple embryos varies greatly among years and is strongly influenced by environmental conditions. This phenomenon has been mainly studied in peach and in the almond cultivars 'Nonpareil' and 'Mission'. Seedlings from the same twin peach seed are frequently viable and show similar growth habits, though occasionally one of the seedlings show weak growth and develops poorly (Hesse, 1971; Gulcan, 1975). Some of these low-vigor plants have been shown to be haploids from which true-breeding dihaploids can be generated (Hesse, 1971) for genetic studies, hybrid rootstock production, and transformation and regeneration studies. Some of the low-vigor, twin almond seedlings were found to be aneuploids (Martínez-Gómez and Gradziel, 2003) and thus, have value for developing near isogenic lines (NIL). A collection of these haploid/aneuploid NILs are presently being developed to aid in genetic (locating genes, selective transfer of particular chromosomes) and molecular (isolation and sequencing of genes, genetic transformation, etc.) studies as demonstrated by Muehlbauer et al. (1988) and Young et al. (1988). 


\section{NEW PROPAGATION TECHNIQUES}

In vitro evaluation of agronomic traits. The possibility of growing plants and even isolated plant cells in a test-tube under controlled in vitro conditions offers unique opportunities for improving selection efficiency. Advantages include minimizing environment influences, the potential to handle large numbers of individuals in a very small space, and accelerated growth and development (Wenzel and Foroughi-Wehr, 1993). The increasing availability of other biotechnological techniques (biochemical markers, DNA analysis, transient reporter transgene expression, genetic transformation, etc.) further complements in vitro culture opportunities.

Wenzel and Foroughi-Wehr (1993) reported the application to herbaceous species of in vitro callus culture for the selection of resistance to environmental stress (freezing tolerance in wheat, salt tolerance in rice) and diseases (Phytophthora sp. and Fusarium sp.), and herbicide tolerance in tobacco. The application of in vitro culture techniques for the selection of horticultural characters, however, may be more difficult. For temperate fruit species, tissue culture propagation has progressed rapidly during the last years. The application of tissue culture techniques as alternative propagation methods has been reported as early as the 1960s. Initially, tissue culture has involved micropropagation and somatic embryogenesis. Axillary shoot production (meristem culture) is the system most frequently utilized to regenerate plantlets by micropropagation techniques (Hammerschlag, 1986, Bornman, 1993; PérezTornero et al., 1999). Research in somatic embryogenesis has recently increased in anticipation of more widespread attempts at regeneration of genetic transformants (Singh and Sansavini, 1998). Tissue culture has numerous potential applications for temperate fruit and nut tree species, including propagation of rootstocks, own-rooted scion cultivars, virus-free stock plants, and elite genotypes (Negueroles and Jones, 1979; Hutchinson, 1987; Gella and Errea, 1998). These techniques also offer unprecedented opportunities for the evaluation of horticultural traits in breeding programs. Applications have been reported in Prunus for the evaluation of the compatibility between cultivar and rootstock (Jonard, 1986), the resistance to abiotic stress (Datée and Branchard, 1986), and the resistance to biotic stress (Martínez-Gómez and Dicenta, 2000).

Recently, a method for measuring in vitro sprouting success for populations of individual vegetative buds of almond has been developed to assess their bud viability (sprouting percentage) and state of dormancy (sprouting rate) (Kester et al., 2003). Two periods of dormancy in the annual growth and development cycle could be distinguished. The first period of growth suppression (paradormancy) occurs during late spring and summer as the trees are subjected to increasing ambient summer temperature and decreasing soil moisture. The second period (endodormancy) occurs during the late fall and winter and is associated with winter chilling. These periods of suppressed bud growth coincide with the occurrence of adverse growth in the desert regions of central Asia where the almond originated. Similar growth conditions occur in the Mediterranean climates of southern Europe, California, Australia and other areas where commercial almond production presently occurs. Results of this research showed that the apparent somaclonal breakdown of a crucial high temperature gene (HTD) controlling paradormancy is associated with the development of noninfectious budfailure (BF), an economically important, epigenetic-like disorder in almond (Kester et al., 2003).

In vivo micrograft. Grafting has been widely used over the centuries for asexual propagation of fruit trees (Hartman and Kester, 1959). Micrografts, developed in the 1970s, involve the grafting of millimeter-size vegetative meristems. Initially, this technique was used for virus elimination in fruit trees. Subsequently, it has been used for the early assessment of rootstock-scion incompatibility, commercial multiplication, virus detection and phytoplasma studies (Navarro et al., 1982; Deogratias et al., 1986; Gebhardt and Goldbach, 1988; Jarausch et al., 2000).

Micrografts proved to be a useful technique when the early propagation of plant material was desired 
and to invigorate weak material. Optimum propagation efficiency is achieved by maximizing the different parameters involved in micropropagation as well as subsequent shoot growth (Martínez-Gómez and Gradziel, 2001a). In vivo micrografting avoids tissue culture transplant shock when transplanting from sterile in vitro conditions. This technique has been employed to recover aneuploids of almond, which occur at low frequencies in sexual embryos with seeds (Martínez-Gómez and Gradziel, 2001b).

Artificial growth cycles. The growth of woody plants from temperate climates requires a periodic endodormancy, which can be artificially achieved through controlled rest periods in cold chambers (Pedryc et al., 1999; Martínez-Gómez et al., 2000b). Two cycles of vegetative growth per year can be carried out by employing two 4-month periods of growth in the greenhouse and two 2-month periods of rest in cold chambers. The size of the pots, the periodic renewal of the soil and the control of mites and fungi are key considerations for the successful management of almond seedlings under these controlled conditions (Martínez-Gómez et al., 2000b). The cold treatments can also be used to control fungi and mites. Seedlings, properly maintained under these conditions, can provide vigorously growing plant tissue (e.g., leaves, root tips) throughout the year. This approach has been used in virus resistance studies, as well as to maintain quarantine conditions (e.g. in the study of dangerous viruses such as the PPV causing sharka disease; Martínez-Gómez et al., 2000a). Artificial cycles of growth have also been used to invigorate weak genetic material such as the aneuploid seedlings of almond (Martínez-Gómez and Gradziel, 2003). Similarly, artificial cold treatments have been successfully utilized in studies of frost tolerance in stone fruit flowers (Pedryc et al., 1999).

\section{USE OF MOLECULAR MARKERS}

Characterization of genotype identity and genetic relationships. Traditionally, the identification and characterization of Prunus cultivars and species has been based on morphological and physiological traits. However, such traits are not always available for analysis and are affected by changing environmental conditions. Molecular marker technology offers several advantages over the sole use of conventional markers. Molecular markers developed for Prunus also offer a powerful tool to study the evolution of the genome, and for understanding of genome structure and determinants of genetic diversity (Wünsch and Hormaza, 2002a).

Isoenzymes: Isoenzymes were among the first genetic markers to be widely utilized. They have been used for cultivar identification in Prunus because of their environmental stability, their codominant expression, and their good reproducibility. Nevertheless, their utilization is limited by the small number of loci that can be analyzed with conventional enzyme staining methods, as well as a low variation in some loci. Electrophoretic surveys were particularly useful in characterizing almond (Arulsekar et al., 1986; Hauagge et al., 1987; Cerezo et al., 1989; Sathe et al., 2001) and plum (Byrne and Littleton, 1988a) cultivars, because both almond and plum are outcrossing species with high level of isoenzyme polymorphisms. In contrast, peach, a predominantly autogamous species, shows few isoenzyme polymorphisms in spite of its extensive morphological variability (Arulsekar et al., 1986; Durham et al., 1987; Mowrey et al., 1990; Agarwal and Nath, 2001). Apricot shows intermediate levels of variability (Arulsekar et al., 1986; Byrne and Littleton, 1989a), with the predominantly outcrossing non-European populations exhibiting higher isoenzyme variability than the predominantly inbreeding European populations (Byrne and Littleton, 1989a). Isoenzyme analysis has also been used to identify different interspecific hybrids (Byrne and Littleton, 1988b, 1989b; Mowrey et al., 1990; Bošković et al., 1997b) and detect phylogenetic relationships among species (Mowrey and Werner, 1990). More recently, isoenzymes in combination with DNA-based markers were employed to create the genetic maps for woody perennials (Weeden, 1994) and for the genetic characterization of multiple embryos in almond (Martínez-Gómez and Gradziel, 2003). 
RFLPs: Restriction fragment length polymorphism (RFLP) markers are based on the differential hybridization of cloned DNA to bulk DNA fragments from restriction-enzyme digestion. Thus, RFLPs are defined by specific enzyme-probe combinations (Tanksley et al., 1989). RFLP markers are codominant. The primary sources of clones for RFLP mapping are cDNA clones and Pstl-derived genomic clones. Genomic clones that represent random sequences may be a poor choice for hybridization probes because of the large percentage of repeated sequences. RFLPs can detect a virtually unlimited number of markers, thus providing an efficient method for discovering linkages among markers and for constructing genetic maps. This is particularly important in Prunus because of the relatively low level of variation typically present in this genus. There are several reports of the use of RFLPs in Prunus for map-based selection (Rajapakse et al., 1995; Viruel et al., 1995; Dirlewanger et al, 1998; Wang et al., 2000) and for elucidating the extent of genetic variability (de Vicente et al., 1998). However, RFLP analysis has important limitations: it is laborious and time-consuming and it often involves the use of radioisotopes. To overcome some of the difficulties, an alternative called sequence tagged sites (STS) has been developed (Olson et al., 1989) which is PCR-based but not requiring radioactive probing. Different STS markers tightly linked to the resistance genes to root-knot nematodes have been successfully developed and can be utilized for introgression of new root-knot nematode resistance genes into peach rootstocks (Yamamoto and Hayashi, 2002).

RAPDs: Random amplified polymorphic DNA (RAPD) markers are based on the PCR amplification of random locations in the genome (Welsh and McClelland, 1990). RAPDs are characterized by using arbitrary primers and permit the quick construction of genetic maps and the saturation of specific genomic regions with molecular markers. A single oligonucleotide is utilized for the amplification of genomic DNA. In contrast to isoenzymes and RFLPs, RAPDs are dominant markers. This feature, as well as their variable degree of repeatability and problems in transferring across populations, limits their utilization primarily to map construction. RAPD techniques have been successfully used in Prunus for identifying cultivars (Lu et al., 1996), estimating genetic diversity and assessing possible origins for selected genotypes (Warburton and Bliss, 1996; Bartolozzi et al., 1998; Martins et al., 2003; MirAli and Nabulsi, 2003), and construction of maps. Problems with DNA quality and a general sensitivity to changes in the reaction conditions can hamper the routine utilization of RAPD markers. These difficulties can be overcome by converting RAPDs to sequence-characterized amplified regions or SCARs (Paran and Michelmore, 1993). In contrast to RAPD and AFLP methods, SCAR is a PCR-based method that employs specific primers. These primers amplify single bands corresponding to genetically defined loci. SCARs can potentially be converted into codominant markers and are less sensitive to reaction conditions. Different SCAR markers are being evaluated for marker-assisted selection in Prunus, including identification of the Mal rootknot nematode resistance gene in Myrobalan plum (Lecouls et al., 1999) and the identification of the $F f$ (flesh adhesion) gene in peach (Jun et al., 2002).

AFLPs: Amplified restriction fragment length polymorphism (AFLP) technology is a powerful DNA fingerprinting technology based on the selective amplification of a subset of genomic restriction fragments using PCR (Vos et al., 1995). DNA is digested with restriction endonucleases and double-stranded specific adapters are ligated to the ends of the DNA fragments to obtain template DNA for subsequent amplification by PCR. The subset of amplified fragments is then analyzed by denaturing PAGE to generate the fingerprint. AFLP has a number of advantages over the RAPD technique: more loci analyzed per experiment and better reproducibility of banding patters resulting from the higher specificity of primer annealing to complementary adapters. Powell et al. (1996) found that AFLPs had a much higher multiplex ratio (number of polymorphic products per "reaction") than other molecular marker systems. Consequently, AFLPs also shows a higher marker index. These 
markers have been mainly used in Prunus for genetic mapping and molecular characterization such as the estimation of genetic diversity among apricot cultivars (Hurtado et al., 2002a).

SSRs: PCR-based, simple sequence repeat (SSR) markers (microsatellites) are becoming the marker of choice for fingerprinting and genetic diversity studies for a wide range of plants (Gupta et al., 1996). Because of their high polymorphism, abundance, and codominant inheritance, they are well suited for the assessment of genetic variability within crop species, and of the genetic relationships among species (Powell et al., 1996). In the case of Prunus species, primer pairs flanking SSRs have been cloned and sequenced in peach (Cipriani et al., 1999; Downey and Iezzoni, 2000; Sosinski et al., 2000; Testolin et al., 2000; Aranzana et al., 2002, 2003a; Dirlewanger et al., 2002; Georgi et al., 2002; Wang et al., 2002; Yamamoto et al., 2002), apricot (Decroocq et al., 2003), and cherry
(Downey and Iezzoni, 2000; Cantini et al., 2001; Schueler et al., 2003). These SSR markers were used for the molecular characterization and identification of cultivars in different species including peach, almond, apricot, cherry and Prunus rootstocks using different methods for the analysis of the DNA (Table 2). In addition, SSR markers were used also for genetic mapping in peach (Sosinski et al., 2000; Dettori et al., 2001; Etienne et al., 2002; Aranzana et al., 2003b), almond (Joobeur et al., 2000; Bliss et al., 2002), and apricot (Hurtado et al., 2002b; Vilanova et al., 2003). Electrophoresis in polyacrilamide with radioactive and silver staining was the first method used in the analysis of the PCR amplified fragment of DNA obtained from the SSR markers. Electrophoresis in Metaphor ${ }^{\circledR}$ agarose was a method used as alternative to the polyacrilamide due to its easier application. More recently, new methods for the PCR amplified DNA have been developed including the utilization of $\mathrm{ABI}^{\circledR}$ sequencer (Table 2).

Table 2. Reports of molecular characterization of Prunus species by microsatellite markers (SSR) using different methods to analyze amplified DNA.

Cuadro 2. Reportes de autores que han efectuado caracterización molecular de especies de Prunus mediante marcadores microsatélites (SSR) utilizando diferentes métodos de análisis del ADN amplificado.

\begin{tabular}{lllll}
\hline \multirow{4}{*}{ Species } & \multicolumn{4}{c}{ Methods for the DNA analysis } \\
\cline { 2 - 5 } Peach & Polyacrylamide Radioactive & Polyacrylamide Silver staining & Metaphor ${ }^{\circledR}$ agarose & ABI $^{\circledR}$ sequencer \\
\hline & Aranzana et al., 2002; & Cipriani et al., 1999; & Cipriani et al., 1999; & Aranzana et al., 2003a; \\
& Georgi et al., 2002; & Dirlewanger et al., 2002; & Dettori et al., 2001; & Wang et al., 2002; \\
& Sosinski et al., 2000; & Bliss et al., 2002; & Martínez-Gómez et al., 2003a & Yamamoto et al., 2002; \\
& Testolin et al., 2000 & Martínez-Gómez et al., 2003a & & Etienne et al., 2002
\end{tabular}

Almond

Apricot Zhebentyayeva et al., 2003

Joobeur et al., 2000;

Bliss et al., 2002;

Martínez-Gómez et al., 2003a

Hurtado et al., 2002a;

Vilanova et al., 2003;

Decroocq et al., 2003

Cherry

$\begin{array}{ll}\text { Downey and Lezzoni, 2000; } & \text { Cantini et al., 2001; } \\ \text { Aranzana } \text { et al., 2002; } & \text { Dirlewanger } \text { et al., 2002; } \\ \text { Schueler } \text { et al., 2003 } & \text { Struss et al., } 2003\end{array}$

Other Prunus Cipriani et al., 1999

Decroocq et al., 2003;
Hormaza, 2002;

Decroocq et al., 2003
Wünsch and Hormaza, 2002b
Martínez-Gómez et al., 2003a

Sánchez-Pérez et al., 2005

Serrano et al., 2002;

Martínez-Gómez et al., 2003b 
Studies of genetic diversity and genetic relatedness utilizing molecular markers thus offer unprecedented opportunities for improving Prunus breeding efficiency when using either established cultivars or interspecific germplasm. Similar opportunities have also been demonstrated for the analysis of chloroplast DNA (Badenes and Parfitt, 1995). SSRs are currently being employed for the molecular characterization and estimation of genetic diversity and the genetic relationships among peach and almond cultivars and related Prunus species (Serrano et al., 2002; Martínez-Gómez et al., 2003b). In addition, recent studies have shown promise for analyzing variation of internal transcribed spacers (ITS) in nuclear ribosomal DNA (Lee and Wen, 2001) and chloroplast DNA (Bortiri et al., 2001).

Genetic mapping. Several intraspecific and interspecific Prunus maps have been developed using different types of molecular markers. The utilization of PCR-based markers has made mapping and tagging of a wide range of traits possible (Arús et al., 1994; Baird et al., 1996). The analysis of cosegregation among markers greatly facilitates linkage analysis between markers and major or quantitative loci controlling horticulturally important traits.

Different research teams have released linkage maps using morphological traits, isoenzymes, RFLPs and RAPDs in peach (Chaparro et al., 1994; Dirlewanger and Bodo, 1994; Rajapakse et al., 1995; Warburton et al., 1996; Abbott et al., 1998; Dirlewanger et al., 1998, 1999; Lu et al., 1998; Sosinski et al., 1998; Dettori et al., 2001; Yamamoto et al., 2001), almond (Viruel et al., 1995; Joobeur et al., 2000; Jauregui et al., 2001; Bliss et al., 2002), sweet cherry (Stockinger et al., 1996), sour cherry (Wang et al., 2000), apricot (Hurtado et al., 2002b; Vilanova et $a l ., 2003)$, and peach $\mathrm{x}$ almond hybrids (Foolad et al., 1995; Joobeur et al., 1998). Similarly, AFLPs allow detection of a higher level of polymorphism in peach than isoenzymes, RFLPs or RAPDs (Dirlewanger et al., 1998, 2003). SSR has also been used for mapping in peach (Dettori et al., 2001; Etienne et al., 2002; Dirlewanger et al., 2003) and almond (Joobeur et al., 2000; Aranzana et al., 2003b). The first genetic linkage map for a Prunus rootstock population was constructed using AFLPs (Lu et al., 1998).

The similar order of markers observed in different Prunus maps suggests a high level of synteny within the genus (Aranzana et al., 2003b; Dirlewanger et al., 2003). This homology among Prunus species partly explains the low level of breeding barriers to interspecific gene introgression and supports the opportunity for successful gene transfer between closely related species.

Another strategy to locate new markers in a known genetic linkage map is the "selective" or "bin" mapping approach. This technique uses a subset of plants that belongs to a population from which a map is already available. This subset of plants is selected to maximize the information on linkage, so that their joint genotype for any marker identifies a unique genome fragment (a bin) as small as possible. This strategy reduces the time and cost of mapping and is adequate to simplify the construction of high density maps or to add large amounts of interesting markers (such as SSRs or EST-derived markers) to a preexistent map. Recently, Howad and Arús (2004) have incorporated 151 SSRs to the Prunus reference map using only 6 individuals from the TxE ('Texas' $\mathrm{x}$ 'Earlygold') Prunus reference population. The use of this set of 6 individuals promises to be a useful resource for Prunus geneticists in future.

Marker-assisted selection. Marker-assisted selection (MAS) is emerging as a very promising strategy for increasing selection gains (Knapp, 1998). If sufficient mapping information is known, MAS can dramatically shorten the number of generations required to "eliminate" the undesired genes of the donor in backcrossing programs (Arús and Moreno-González, 1993). Marker loci linked to major genes can be used for selection, which is sometimes more efficient than direct selection for the target gene (Arús and Moreno-González, 1993; Baird et al., 1996). Selection by molecular markers is particularly useful in fruit, nut, and other tree crops with a long juvenile period, and when the 
expression of the gene is recessive or the evaluation of the character is otherwise difficult, as with resistance to biotic or abiotic stress (Luby and Shaw, 2001; Scorza, 2001; Testolin, 2003).

The principal approach for the analysis of markertrait association in Prunus is the use of mapping populations segregating for the characters of interest. The different linkage maps developed in Prunus (peach, almond, cherry, and apricot) include markers associated with several traits of horticultural value. Mapping quantitative characters by identifying quantitative trait loci (QTL) is also becoming an important tool in tree breeding. QTLs are generally recognized by comparing the degree of covariation for polymorphic molecular marker with phenotypic trait measurements. Important characters and QTLs that are presently being mapped in stone fruits include the control of flower (bloom time, self-incompatibility, pollen-sterility, double-flowers), fruit (shape, pubescence, flesh color, acidity and sweetness), leaf (red vs. green color) and tree (pillar or weeping architectures) traits, and resistance to various pests and diseases including root-knot nematodes, powdery mildew, leaf curl, and Plum pox potyvirus (Asins et al., 1994; Dirlewanger et al., 1996, 1998, 1999; Abbott et al., 1998; Ballester et al., 1998, 2001; Bliss et al., 2002; Etienne et al., 2002; Hurtado et al., 2002b) (Tables 3 and 4). The high degree of genome synteny observed among Prunus species (Aranzana et al., 2003b; Dirlewanger et al., 2003) should also facilitate the successful transfer of sets of markers and coding sequence among species.

Bulk segregant analysis (BSA), where two pooled DNA samples are formed from plant sources that have similar genetic backgrounds but differ in one particular trait, is another promising approach for the analysis of molecular marker-horticultural trait association. This method also makes possible the identification of markers linked to the trait of interest (Michelmore et al., 1991). A strategy combining different markers with bulk segregant analysis was used to identify markers linked to loci of specific characters in peach and peach $\mathrm{X}$ almond crosses (Warburton et al., 1996), RAPD markers flanking the red-leaf ( $\mathrm{Gr})$ and malate dehydrogenase loci in the NC174RL x Pillar and Marsun $x$ White Glory F2 peach families (Chaparro et al., 1994), and three RAPD markers associated with a gene conferring delayed bloom in almond (Ballester et al., 2001). BSA has facilitated the study of self-incompatibility and male sterility in almond (Badenes et al., 2000). BSA and RAPD analysis were recently utilized to distinguish markers linked to the Mal gene, a major dominant gene that controls a wide-spectrum resistance to root-knot nematodes in Myrobalan plum (Lecouls et al., 1999), as well as markers linked to resistance to PPV in apricot (Salava et al., 2001) and to ring nematode in peach (Blenda et al., 2002) (Table 3).

The first genetic linkage map for a Prunus rootstock population was constructed using AFLP technology (Lu et al., 1998) and, simultaneously, two genes that control resistance to root-knot nematodes, $M i$ and $M i j$, were mapped and tagged. The conversion of the AFLP marker linked to the Mij (a gene required for resistance to Meloidogyne incognita and javanica) locus to STS proved to have practical application for germplasm screening and for breeding peach rootstocks for resistance to rootknot nematodes (Lu et al., 1999, Yamamoto and Hayashi, 2002) (Table 3).

Apart from isoenzymes, RFLP, RAPD, AFLP, and SSR, other markers being used in the development of marker associated traits, are those based on single point mutations (SNPs) and those obtained from either cDNA sequences (ESTs) or databases (Cloned Gene Analogs, CGAs) (Van Nocker et al., 2002; Testolin, 2003). The large-scale single-pass sequencing of ESTs can give a global picture of the genes involved in the development and function of organs and tissues. A recent collection of ESTs from peach and almond based on cDNA libraries has been released to public databases, and more than 3,800 putative unigenes have been detected (www.genome.clemson.edu/gdr/). This work is complementary to others regarding EST development in Prunus. A collection of 6,817 ESTs was prepared using four cDNA libraries obtained from peach mesocarp (Lazzari et al., 2004) in relation 
to the program of the Italian National Consortium for Peach Genomics (www.itb.cnr.it/ESTree). Also, the release of Prunus microarrays using unigene sets as probes has started. A group of nearly 4,600 unique ESTs derived from peach mesocarp and developing almond seeds have been sequenced to analyze the expression profile of the unigene set during fruit development and the identification of additional genes involved in this process (McCord et al., 2004).

Table 3. Markers associated to main monogenic or oligogenic traits in Prunus.

Cuadro 3. Marcadores asociados a los principales caracteres monogénicos u oligogénicos en Prunus.

\begin{tabular}{|c|c|c|c|c|}
\hline Specie & Trait & Symbol & Marker $^{1}$ & Reference \\
\hline \multirow[t]{25}{*}{ Peach } & Leaf color & $\mathrm{Gr}$ & RAPD & Chaparro et al., 1994 \\
\hline & Leaf color & $\mathrm{Gr}$ & SSR & Yamamoto et al., 2001 \\
\hline & Leaf glands & $\mathrm{E}$ & RFLP & Dettori et al., 2001 \\
\hline & Leaf glands & $\mathrm{E}$ & RFLP & Quarta et al., 2000 \\
\hline & Double flower & Dl & AFLP & Sosinski et al., 2000 \\
\hline & Male sterility & Ps & AFLP & Dirlewanger et al., 1999 \\
\hline & Skin hairiness & G & AFLP & Dirlewanger et al., 1999 \\
\hline & Skin hairiness & G & RFLP & Bliss et al., 2002 \\
\hline & Skin color & Sc & SSR & Yamamoto et al., 2001 \\
\hline & Flat fruit & $\mathrm{S}$ & RFLP & Dirlewanger et al., 1999 \\
\hline & Flesh color & $\mathrm{Y}$ & RAPD & Warburton et al., 1996 \\
\hline & Flesh color & $\mathrm{Y}$ & AFLP & Abbott et al., 1998 \\
\hline & Flesh color & $\mathrm{Y}$ & RFLP & Bliss et al., 2002 \\
\hline & Flesh adhesion & $\mathrm{F}$ & RFLP & Abbott et al., 1998 \\
\hline & Flesh adhesion & $\mathrm{F}$ & RFLP & Dettori et al., 2001 \\
\hline & Flesh adhesion & $\mathrm{F}$ & RFLP & Quarta et al., 2000 \\
\hline & Flesh adhesion & $\mathrm{F}$ & AFLP & Yamamoto et al., 2001 \\
\hline & Non acid fruit & $\mathrm{D}$ & RAPD & Dirlewanger et al., 1999 \\
\hline & Non acid fruit & $\mathrm{D}$ & RFLP & Bliss et al., 2002 \\
\hline & Nematode resistance & Mij & AFLP & Abbott et al., 1998 \\
\hline & Nematode resistance & Mij & AFLP & Lu et al., 1998 \\
\hline & Nematode resistance & Mij & STS & Lu et al., 1999 \\
\hline & Nematode resistance & Mia & AFLP & Yamamoto and Hayashi, 2002 \\
\hline & Nematode resistance & Mja & STS & Yamamoto and Hayashi, 2002 \\
\hline & Nematode resistance & $\mathrm{Mja}$ & AFLP & Blenda et al., 2002 \\
\hline \multirow[t]{5}{*}{ Almond } & Self-incompatibility & SI & RFLP & Joobeur et al., 1998 \\
\hline & Self-compatibility & Sf & RFLP & Arús et al., 1999 \\
\hline & Kernel taste & Sw & RFLP & Bliss et al., 2002 \\
\hline & Shell hardiness & $\mathrm{D}$ & RFLP & Arús et al., 1999 \\
\hline & Late blooming & $\mathrm{Lb}$ & RAPD & Ballester et al., 2001 \\
\hline \multirow[t]{5}{*}{ Apricot } & PPV resistance & Ppv & SSR & Hurtado et al., 2002b \\
\hline & PPV resistance & Ppv & AFLP & Salava et al., 2001 \\
\hline & PPV resistance & $\mathrm{Ppv}$ & SSR & Vilanova et al., 2003 \\
\hline & Self-incompatibility & SI & RAPD & Badenes et al., 2000 \\
\hline & Male sterility & Ps & RAPD & Badenes et al., 2000 \\
\hline \multirow[t]{3}{*}{ Cherry } & Self-incompatibility & SI & EST & Tao et al., 1997 \\
\hline & Self-compatibility & $\mathrm{SC}$ & EST & Sonneveld et al., 2001 \\
\hline & Dwarf habit & Dw & RFLP & Arús et al., 1999 \\
\hline \multirow[t]{2}{*}{ Plum } & Nematode resistance & Ma1 & RAPD & Salesses et al., 1998 \\
\hline & Nematode resistance & Ma1 & SCAR & Lecouls et al., 1999 \\
\hline
\end{tabular}

${ }^{1}$ RAPD: Random amplified polymorphic DNA, SSR: Simple sequence repeat, RFLP: Restriction fragment length polymorphism, AFLP: Amplified restriction fragment length polymorphism, EST: Expressed sequence tags, STS: Sequence tagged site, SCAR: Sequence characterized amplified region. 
Table 4. Markers associated to main polygenic traits (QTLs) in Prunus.

Cuadro 4. Marcadores asociados a los principales caracteres poligénicos (QTLs) en Prunus.

\begin{tabular}{|c|c|c|c|}
\hline Specie & Trait & Marker $^{1}$ & Reference \\
\hline \multirow[t]{35}{*}{ Peach } & Leaf curl resistance & RAPD & Viruel et al., 1998 \\
\hline & Internode length & RFLP & Verde et al., 2002 \\
\hline & Powdery mildew resistance & RFLP & Quarta et al., 2000 \\
\hline & Flowering time & RFLP & Dirlewanger et al., 1999 \\
\hline & Flowering time & RFLP & Quarta et al., 2000 \\
\hline & Flowering time & RFLP & Verde et al., 2002 \\
\hline & Ripening time & RFLP & Quarta et al., 2000 \\
\hline & Ripening time & SSR & Verde et al., 2002 \\
\hline & Ripening time & RFLP & Dirlewanger et al., 1999 \\
\hline & Maturity time & SSR & Etienne et al., 2002 \\
\hline & Fruit develop cycle & RFLP & Abbott et al., 1998 \\
\hline & Fruit develop cycle & SSR & Etienne et al., 2002 \\
\hline & Productivity & RFLP & Dirlewanger et al., 1999 \\
\hline & Fruit diameter & AFLP & Abbott et al., 1998 \\
\hline & Fruit weight & RFLP & Abbott et al., 1998 \\
\hline & Fruit weight & RFLP & Etienne et al., 2002 \\
\hline & Fruit skin color & RFLP & Quarta et al., 2000 \\
\hline & Fruit skin color & SSR & Verde et al., 2002 \\
\hline & $\mathrm{pH}$ & RFLP & Abbott et al., 1998 \\
\hline & $\mathrm{pH}$ & RFLP & Etienne et al., 2002 \\
\hline & Titratable acidity & RFLP & Dirlewanger et al., 1999 \\
\hline & Titratable acidity & RFLP & Etienne et al., 2002 \\
\hline & Malic acid content & RFLP & Dirlewanger et al., 1999 \\
\hline & Malic acid content & RFLP & Etienne et al., 2002 \\
\hline & Citric acid content & RFLP & Dirlewanger et al., 1999 \\
\hline & Citric acid content & RFLP & Etienne et al., 2002 \\
\hline & Soluble solids & RFLP & Abbott et al., 1998 \\
\hline & Soluble solids & RFLP & Quarta et al., 2000 \\
\hline & Soluble solids & SSR & Etienne et al., 2002 \\
\hline & Soluble solids & SSR & Verde et al., 2002 \\
\hline & Fructose content & AFLP & Abbott et al., 1998 \\
\hline & Fructose content & RFLP & Etienne et al., 2002 \\
\hline & Glucose content & RFLP & Abbott et al., 1998 \\
\hline & Glucose content & RFLP & Dirlewanger et al., 1999 \\
\hline & Glucose content & RFLP & Etienne et al., 2002 \\
\hline Almond & Shell hardiness & RFLP & Arús et al., 1999 \\
\hline \multirow[t]{4}{*}{ Cherry } & Blooming time & RFLP & Wang et al., 2000 \\
\hline & Ripening time & RFLP & Wang et al., 2000 \\
\hline & Fruit weight & RFLP & Wang et al., 2000 \\
\hline & Soluble solids & RFLP & Wang et al., 2000 \\
\hline
\end{tabular}

'RAPD: Random amplified polymorphic DNA, SSR: Simple sequence repeat, RFLP: Restriction fragment length polymorphism, AFLP: Amplified restriction fragment length polymorphism.

A very promising application of molecular marker assisted selection is for the manipulation of selfcompatibility in Prunus. Most species are predominantly self-incompatibles. Selfincompatibility is of the gametophytic type and acts to prevent self-fertilization. This character is controlled by a single locus with multiple codominant alleles (Dicenta and García, 1993; Burgos et al., 1997), and is expressed within the styles of flowers as $S$-RNases glycoproteins 
(Bošković et al., 1997a, 2003; Tao et al., 1997; Yaegaki et al., 2001) that are responsible of the subsequent inactivation of self-pollen tube growth. Almond self-incompatibility alleles ( $S$-alleles) were initially identified in the field through controlled crosses with a series of known $S$ genotypes (Kester and Gradziel, 1996). More recently, molecular methods have been developed in two areas: identification of stylar $S$-RNases by electrophoresis in vertical polyacrilamide gels (Bošković et al., 1997a, 1999, 2003; Burgos et al., $1998)$, and the amplification of specific $S$-alleles using appropriately designed primers for PCR and electrophoresis in horizontal agarose gels (Tamura et al., 2000; Tao et al., 2000; Channuntapipat et al., 2001; Sonneveld et al., 2001, 2003). This technique is being routinely used for the identification of cross-incompatibility groupings for current almond cultivars and for efficiently breeding self-compatibility into new cultivars (Gradziel et al., 2001b; Ortega and Dicenta, 2003; Sánchez-Pérez et al., 2004).

\section{GENE-TRANSFER TECHNOLOGIES}

Genetic engineering can reduce the time and space required to improve fruit and tree characteristics compared with traditional plant breeding methodologies. A specific genetic change, with no addition of associated detrimental genes, can be accomplished rapidly, whereas traditional breeding programs require more generations and extensive acreage. Genetic engineering can also increase the diversity of genes and germplasm available by allowing the stable integration of foreign DNA into the plant genome. In the case of fruit trees, genetic engineering represents an alternative to overcome handicaps of traditional Prunus breeding programs (i.e. long juvenility period, self-incompatibility, evaluation of agronomic traits in the field, etc.) (Singh and Sansavini, 1998; Singh, 2000).

Even discrete genetic changes to a seemingly beneficial genotype can have unanticipated and undesirable consequences. Both the 'TardyNonpareil' and the "Jeffries' mutation of the commercially important almond cultivar 'Nonpareil', while conferring the very desirable traits of late flowering and unilateral crosscompatibility with 'Nonpareil', respectively, failed commercially due to losses in tree productivity associated with the genetic change (Kester and Gradziel, 1996). In addition, the presence of genetic mosaics in regenerated transgenic plantlets could lead to later problems with losses of cultivar trueness-to-type in vegetatively propagated crops (Marcotrigiano and Gradziel, 1997).

Most transgenic Prunus plants have been obtained via Agrobacterium-mediated transformation because of its efficacy (Mante et al., 1990, 1991; Scorza et al., 1990; Smigocki and Hammerschlag, 1991; Cámara Machado et al., 1994; Archilletti et al., 1995, Miguel and Oliveira, 1999; Petri and Burgos, 2005). Much of this research involved the introduction of reporter genes in seedling tissues. The gus gene, which codes for $\beta$-glucuronidase, has been successfully utilized as a marker gene in genetic transformation of almond (Archilletti et al., 1995), peach (Xiaojian et al., 1994) and plum (Mante et al., 1990, 1991; Cámara Machado et al., 1994; Scorza et al., 1994). In addition, nptII (neomycin phosphotranspherase) gene, which confers kanamycin resistance, has been used in these species (Mante et al., 1990, 1991; Scorza et al., 1994; Archilletti et al., 1995). Peach has been also transformed using microprojectile bombardment-based protocols with integration of gus and nptII genes (Xiaojian et al., 1994). The recovery of transgenic forms of established cultivars, while being most desirable owing to their commercial acceptance, has had only limited success since these older cultivars have lost most juvenile-growth characteristics including the capacity for efficient regeneration from single cells (Marcotrigiano and Gradziel, 1997).

To manipulate tree architecture, transgenic peach seedlings expressing the ipt gene (which increases endogenous cytokinin levels and reduces apical dominance) were obtained (Hammerschlag and Smigocki, 1998). These plants showed reduced height and increased branching. In addition, 
transgenic apricots and plums bearing the coat protein gene of the Plum pox virus (PPV) were successfully developed (Cámara Machado et al., 1992, 1994; Scorza et al., 1994). Transgenic plants, as well as the hybrids generated from them, showed a high level of resistance to PPV (Scorza et al., 1994, 1998; Ravelonandro et al., 1997). The transgenic plum clone C5 exhibited high level of resistance to graft inoculation of PPV and an apparent immunity to aphid-vectored infection in field tests. These results demonstrate the impact that can be achieved in the Prunus resistance to virus by gene-silencing (Scorza and Ravelonandro, 2002).

Currently, complex traits such as yield and flavor are not likely candidates for improvement by biotechnology. Moreover, there is a need for genes from Prunus to be cloned, since public concern about transgene technology makes a distinction between native and non-native genes. There is also a need for fruit- or leaf-specific promoters, so that gene expression may be targeted only to the parts of the plant necessary for the desired effect (Petri and Burgos, 2005). Finally, transgenic testing should ensure that there are no non-target effects and that transgenic lines are stable and nonchimeric.

\section{CONCLUSIONS}

The typical long generation time, along with the extensive space requirements and other limitations to generating the required large segregating progeny populations, have frustrated the development and testing of new, often molecular-based, breeding strategies. These same limitations, however, make new strategies that improve breeding efficiency particularly valuable to tree crops. In addition, most Prunus tree crops, because they are vegetatively propagated, have a unique advantage over other agronomic crops since desirable, unique gene combinations can be 'captured' by clonal propagation. A number of technologies will enable researchers to learn not only which Prunus genes are expressed but also their level of expression in a given cell type under specified conditions.
Quantitative technologies for evaluating differential gene expression include not only quantitative PCR (qPCR), but also serial analysis of gene expression (SAGE), microarrays, differential display, and massively parallel signature sequencing (MPSS). Results from their use will help to answer longstanding questions, such as how cells respond to changes in their environment. Drought tolerance, for example, may be determined by many genetic factors. The "one-gene-at-a-time" approach for analyzing gene function is inadequate. It is now possible to locate multiple genes of tree crops in responding to environmental stresses. There are several major new molecular tools used for gene functional analysis, such as EST and microarray technology. Genetic engineering offers an alternative approach to accelerate traditional Prunus breeding programs. A number of genetically modified Prunus species have been obtained using different gene transfer methods though additional research is needed for developing new transgenes of value to tree crops as well as methods for the efficient regeneration of commercially established cultivars. Additional advantages encouraging the utilization of these new technologies to Prunus tree crop improvement include a small genome size, high levels of synteny between genomes, and a well-established international network of cooperation among researchers.

\section{RESUMEN}

La utilización de nuevo germoplasma, el desarrollo de marcadores moleculares, la utilización de técnicas alternativas de propagación y la transferencia de genes, se cuentan entre las novedosas herramientas aplicables al mejoramiento de Prunus. En la utilización de nuevo germoplasma, se persigue la introducción de genes de especies de Prunus silvestres que confieren caracteres agronómicamente valiosos tales como la autocompatibilidad, el hábito de crecimiento mejorado, la resistencia a la sequía, y la mejora de la calidad del fruto o semilla. Por otro lado, los estudios con semillas poliembriónicas (dos embriones dentro de una misma cubierta seminal) pueden facilitar los estudios genéticos $\mathrm{y}$ 
citogenéticos de estas especies. Entre los métodos de propagación alternativos se encuentran las técnicas in vitro para la evaluación del material vegetal, y las técnicas de microinjerto in vivo que permiten la propagación temprana de genotipos de alto riesgo. Además, el cultivo de los Prunus bajo condiciones controladas en invernadero, incluyendo la inducción de un período de reposo artificial mediante el uso de tratamientos en cámara fría, provee una estrategia útil para obtener plantas de crecimiento vigoroso durante todo el año. Los marcadores moleculares también se han constituido en una herramienta esencial para los estudios de mejoramiento genético en Prunus. Se han utilizado distintas clases de marcadores moleculares, incluyendo isoenzimas, RFLPs, RAPDs, AFLPs y SSRs, para la caracterización genética del germoplasma, el establecimiento de relaciones génicas entre cultivares y especies, y la construcción de mapas genéticos. Las metodologías para el análisis de la selección asistida por marcadores incluye el uso del mapeo de poblaciones segregantes para caracteres deseables y el análisis de grupos segregantes. La ingeniería genética ofrece una resolución a problemas que enfrentan los programas de mejoramiento tradicionales de Prunus, incluyendo un período juvenil prolongado y requerimientos de grandes espacios para las poblaciones en cruzamiento. Se ha obtenido un número apreciable de cultivares de Prunus genéticamente modificados utilizando diferentes métodos de transferencia de genes. Sin embargo, se requiere aún trabajo de investigación adicional para desarrollar completamente la próxima generación de vectores de genes y plantas transgénicas.

Palabras clave: Almendro, cerezo, ciruelo, damasco, duraznero, germoplasma, marcadores moleculares, técnicas de propagación, transferencia de genes.

\section{REFERENCES}

Abbott, A.G., S. Rajapakse, B. Sosinski, Z.X. Lu, K. Sossey-Alaoui, M. Gannavarapu, R. Scorza, G. Reighard, R.E. Ballard, A. Callahan, and
W.V. Baird. 1998. Construction of saturated linkage maps of peach crosses segregating for characters controlling fruit quality, tree architecture and pest resistance. Acta Horticulturae 465: 141-150.

Agarwal, S., and A.K. Nath. 2001. Characterisation of peach (Prunus persica L.) cultivars using isozymes as molecular markers. Scientia Horticulturae 90: 227-242.

Aranzana, M.J., J. Carbó, and P. Arús. 2003a. Microsatellite variability in peach [Prunus persica (L.) Batsch]: cultivar identification, marker mutation, pedigree inferences and population structure. Theoretical and Applied Genetics 106: 1341-1352.

Aranzana, M.J., J. García-Mas, J. Carbó, and P. Arús. 2002. Development and variability analysis of microsatellite markers in peach. Plant Breeding 121: 87-92.

Aranzana, M.J., A. Pineda, P. Cosson, E. Dirlewanger, J. Ascasibar, G. Cipriani, C.D. Ryder, R. Testolin, A. Abbott, G.J. King, A.F. Iezzoni, and P. Arús. 2003b. A set of simplesequence (SSR) markers covering the Prunus genome. Theoretical and Applied Genetics 106: 819-825.

Archilletti, T., P. Lauri, and C. Damiano. 1995. Agrobacterium-mediated transformation of almond leaf pieces. Plant Cell Reports 14: 267-272.

Arulsekar, S., D.E. Parfitt, and D.E. Kester. 1986. Comparison of isozyme variability in peach and almond cultivars. Journal of Heredity 77 : 272-274.

Arús, P., J. Ballester, B. Jauregui, T. Joobeur, M.J. Truco, and M.C. de Vicente. 1999. The European Prunus mapping project: update of marker development in almond. Acta Horticulturae 484: 331-336.

Arús, P., R. Messeguer, M.A. Viruel, K. Tobutt, E. Dirlewanger, F. Santi, R. Quarta, and E. Ritter. 1994. The European Prunus mapping project. Euphytica 77: 97-100.

Arús, P., and J. Moreno-González. 1993. Markerassisted selection. p. 314-331. In: M.D. Hayward, N.O. Bosemark, and I. Romagosa (ed.) Plant Breeding. Principles and Prospects. 
Chapman \& Hall, London, United Kingdom. Asins, M.J., P. Mestre, J.E. García, F. Dicenta, and E.A. Carbonell. 1994. Genotype x environment interaction in QTL analysis of an intervarietal almond cross by means of genetic markers. Theoretical and Applied Genetics 89: 358-364. Badenes, M.L., M.A. Hurtado, F. Sanz, D.M. Archelos, L. Burgos, J. Egea, and G. Yacer. 2000. Searching for molecular markers linked to male sterility and self-compatibility in apricot. Plant Breeding 119: 157-160. Badenes, M.L., and D.E. Parfitt. 1995. Phylogenetic relationships of cultivated Prunus species from an analysis of chloroplast DNA. Theoretical and Applied Genetics 90: 1035-1041.

Baird, W.V., R.E. Ballard, S. Rajapakse, and A.G. Abbott. 1996. Progress in Prunus mapping and application of molecular markers to germplasm improvement. HortScience 31: 1099-1106.

Ballester, J., R. Bǒsković, I. Batlle, P. Arús, F. Vargas, and M.C. de Vicente. 1998. Location of the self-incompatibility gene on the almond linkage map. Plant Breeding 117: 69-72.

Ballester, J., R. Socias i Company, P. Arús, and M.C. de Vicente. 2001. Genetic mapping of a major gene delaying blooming time in almond. Plant Breeding 120: 268-270.

Bartolozzi, F., M.L. Warburton, S. Arulsekar, and T.M. Gradziel. 1998. Genetic characterization and relatedness among California almond cultivars and breeding lines detected by randomly amplified polymorphic DNA (RAPD) analysis. Journal of the American Society for Horticultural Science 123: 381-387.

Bernhard, R. 1949. The peach-almond and its utilization. Revue Horticole 121: 97-101. Blenda, A.V., G.L. Reighard, W.V. Baird, L.L. Georgi, and A.G. Abbott. 2002. Molecular markers and candidate resistance genes: a genetic study of tolerance to ring nematode in peach. www.intl-pag.org. Plant, Animal \& Microbe Genomes X Conference. San Diego, USA. Bliss, F.A., S. Arulsekar, M.R. Foolad, V. Becerra, A. Gillen, M.L. Warburton, A.M. Dandekar, G.M. Kocsine, and K.K. Mydin. 2002. An expanded genetic linkage map of Prunus based on an interspecific cross between almond and peach. Genome 45: 520-529.

Bornman, C.H. 1993. Micropropagation and somatic embryogenesis. p. 246-260. In: M.D. Hayward, N.O. Bosemark, and I. Romagosa (ed.) Plant Breeding. Principles and Prospects. Chapman \& Hall, London, United Kingdom. Bortiri, P.E., S. Oh, J. Jiang, S. Baggett, A. Granger, C. Weeks, M. Buckingham, D. Potter, and D.E. Parfitt. 2001. Phylogeny and systematics of Prunus (Rosaceae) as determined by sequence analysis of ITS and the chloroplast trnL-trnF spacer DNA. Systematic Botany 26: 797-807.

Bǒsković, R., K.R. Tobutt, I. Batlle, and H. Duval. 1997a. Correlation of ribonuclease zymograms and incompatibility genotypes in almond. Euphytica 97: 167-176.

Bǒsković, R., K.R. Tobutt, I. Batlle, H. Duval, P. Martínez-Gómez, and T.M. Gradziel. 2003. Stylar ribonucleases in almond: correlation with and prediction of self-incompatibility genotypes. Plant Breeding 122: 70-76. Bǒsković, R., K.R. Tobutt, H. Duval, I. Batlle, F. Dicenta, and F.J. Vargas. 1999. A stylar ribonuclease assay to detect self-compatible seedlings in almond progenies. Theoretical and Applied Genetics 99: 800-810.

Bǒsković, R., K.R. Tobutt, and J.F. Nicoll. 1997b. Inheritance of isoenzymes and their linkage relationships in two interspecific cherry progenies. Euphytica 93: 129-143.

Browicz, K., and D. Zohary. 1996. The genus Amygdalus L. (Rosaceae): Species relationship, distribution and evolution under domestication. Genetic Resources and Crop Evolution 43: 229-247.

Burgos, L., J. Egea, R. Guerriero, R. Viti, P. Monteleone, and J.M. Audergon. 1997. The self-compatibility trait of the main apricot cultivars and new selections from breeding programs. Journal of Horticultural Science 72: 147-154.

Burgos, L., O. Pérez-Tornero, J. Ballester, and E. Olmos. 1998. Detection and inheritance of stylar ribonucleases associated with incompatibility alleles in apricot. Sexual Plant Reproduction 11: 153-158. 
Byrne, D.H., and T.G. Littleton. 1988a. Electrophoretic characterization of diploid plums of the Southeastern United States. Journal of the American Society for Horticultural Science 113: 918-924. Byrne, D.H., and T.G. Littleton. 1988b. Verification of the parentage of presumed peach $\mathrm{x}$ almond hybrids by isozyme analyses. Fruit Varieties Journal 42: 130-134.

Byrne, D.H., and T.G. Littleton. 1989a. Characterization of isozyme variability in apricots. Journal of the American Society for Horticultural Science 114: 674-678. Byrne, D.H., and T.G. Littleton. 1989b. Interspecific hybrid verification of plum $\mathrm{x}$ apricot hybrids via isozyme analyses. HortScience 24: 132-134.

Cámara Machado, A., H. Katinger, and M.L. Cámara Machado. 1994. Coat protein-mediated protection against plum pox virus in herbaceous model plants and transformation of apricot and plum. Euphytica 77: 129-134.

Cámara Machado, M.L., A. Cámara Machado, V. Hanzer, H. Weiss, F. Regner, H. Steinkellner, D. Mattanovich, R. Plail, E. Knapp, B. Kalthaff, and H. Katinger. 1992. Regeneration of transgenic plants of Prunus armeniaca containing the coat protein gene of plum pox virus. Plant Cell Reports 11: 25-29.

Cantini, C., A.F. Iezzoni, W.F. Lamboy, M. Boritzki, and D. Struss. 2001. DNA fingerprinting of tetraploid cherry germplasm using simple sequence repeats. Journal of the American Society for Horticultural Science 126: 205-209. Cerezo, M., R. Socias i Company, and P. Arús. 1989. Identification of almond cultivars by pollen isoenzymes. Journal of the American Society for Horticultural Science 114: 164-169. Channuntapipat, C., M. Sedgley, and G. Collins. 2001. Sequences of the cDNAs and genomic DNAs encoding the S1, S7, S8, and Sf alleles from almond, Prunus dulcis. Theoretical and Applied Genetics 103: 1115-1122. Chaparro, J.X., D.J. Werner, D. O’Malley, and R.R. Sederoff. 1994. Targeted mapping and linkage analysis of morphological isozyme, and RAPD markers in peach. Theoretical and Applied Genetics 87: 805-815.
Cipriani, G., G. Lot, W.G. Huang, M.T. Marrazzo, E. Peterlunger, and R. Testolin. 1999. AC/GT and $\mathrm{AG} / \mathrm{CT}$ microsatellite repeats in peach [Prunus persica (L) Batsch]: isolation, characterisation and cross-species amplification in Prunus. Theoretical and Applied Genetics 99: 65-72.

Datée, Y., and Branchard, M. 1986. In vitro culture and cellular biotechnologies applied to plant breeding. Present state and perspectives. Acta Horticulturae 193: 17-28.

de Vicente, M.C., M.J. Truco, J. Egea, L. Burgos, and P. Arús. 1998. RFLP variability in apricot (Prunus armeniaca L.). Plant Breeding 117: 153-158.

Decroocq, V., M.G. Favé, L. Hagen, L. Bordenave, and S. Decroocq. 2003. Development and transferability of apricot and grape EST microsatellite markers across taxa. Theoretical and Applied Genetics 106: 912-922. Denisov, V.P. 1988. Almond genetic resources in the USSR and their use in production and breeding. Acta Horticulturae 224: 299-306.

Deogratias, J.M., A. Lutz, and F. Dosba. 1986. In vitro micrografting of shoot tips from juvenile and adult Prunus avium (L.) and Prunus persica (L.) Batsch to produce virus-free plants. Acta Horticulturae 193: 139-145.

Dettori, M.T., R. Quarta, and I. Verde. 2001. A peach linkage map integrating RFLPs, SSRs, RAPDs, and morphological markers. Genome 44: 783-790.

Dicenta, F., and J.E. García. 1993. Inheritance of self-compatibility in almond. Heredity 70 : 313-317.

Dirlewanger, E., and C. Bodo. 1994. Molecular genetic mapping of peach. Euphytica 77: 101-103.

Dirlewanger, E., A. Crosson, C. Poizat, M.J. Aranzana, M. Dettori, I. Verde, R. Quarta, P. Arús, and L. Laigret. 2003. Synteny within the Prunus genomes detected by microsatellite markers. Acta Horticulturae 633: 177-187.

Dirlewanger, E., A. Crosson, P. Tavaud, M.J. Aranzana, C. Poizat, A. Zanetto, P. Arús, and L. Laigret. 2002. Development of microsatellite markers in peach and their use 
in genetic diversity analysis in peach and sweet cherry. Theoretical and Applied Genetics 105: 127-138.

Dirlewanger, E., A. Moing, C. Rothan, L. Svanella, V. Pronier, A. Guye, C. Plomion, and R. Monet. 1999. Mapping QTLs controlling fruit quality in peach (Prunus persica (L.) Batsch). Theoretical and Applied Genetics 98: 18-31. Dirlewanger, E., T. Pascal, C. Zuger, and J. Kervella. 1996. Analysis of molecular markers associated with powdery mildew resistance genes in peach (Prunus persica (L.) Batsch) $\mathrm{x}$ Prunus davidiana hybrids. Theoretical and Applied Genetics 93: 909-919.

Dirlewanger, E., V. Pronier, C. Parvery, C. Rothan, A. Guye, and R. Monet. 1998. Genetic linkage map of peach [Prunus persica (L.) Batsch] using morphological and molecular markers. Theoretical and Applied Genetics 97: 888-895.

Downey, L.D., and A.F. Lezzoni. 2000. Polymorphic DNA markers in black cherry (Prunus serotina) are identified using sequences from sweet cherry, peach, and sour cherry. Journal of the American Society for Horticultural Science 125: 76-80.

Durham, R.E., G.A. Moore, and W.B. Sherman. 1987. Isozyme banding patterns and their usefulness as genetic markers in peach. Journal of the American Society for Horticultural Science 112: 1013-1018.

Esquinas-Alcazar, J.T. 1993. Plant genetic resources. p. 33-51. In: M.D. Hayward, N.O. Bosemark, and I. Romagosa (eds.) Plant Breeding. Principles and Prospects. Chapman \& Hall, London, United Kingdom.

Etienne, C., C. Rothan, A. Moing, C. Plomion, C. Bodenes, L. Svanella-Dumas, P. Cosson, V. Pronier, R. Monet, and E. Dirlewanger. 2002. Candidate genes and QTLs for sugar and organic content in peach [Prunus persica (L.) Batsch]. Theoretical and Applied Genetics 105: 145-159.

FAO. 2003. FAO Statistical Databases: Agriculture. http://apps.fao.org. Food and Agriculture Organization of the United Nations.

Faust, M., and D. Surányi. 1997. Origin and dissemination of cherry. Horticultural Reviews
19: 263-317.

Faust, M., and D. Surányi. 1999. Origin and dissemination of plums. Horticultural Reviews 23: 179-231.

Faust, M., D. Surányi, and F. Nyujtó. 1998. Origin and dissemination of apricot. Horticultural Reviews 22: 225-266.

Faust, M., and D. Timon. 1995. Origin and dissemination of peach. Horticultural Reviews 17: 331-379.

Felipe, A.J. 1975. F1 hybrids of peach and almond trees as a model for both species. Agricultura 44: 661-663.

Foolad, M.R., S. Arulsekar, V. Becerra, and F.A. Bliss. 1995. A genetic map of Prunus based on an interspecific cross between peach and almond. Theoretical and Applied Genetics 91: 262-269.

Gebhardt, K., and H. Goldbach. 1988. Establishment, graft union characteristics and growth of Prunus micrograft. Physiologia Plantarum 72: 153-159.

Gella, R., and P. Errea. 1998. Application of in vitro therapy for ilarvirus elimination in three Prunus species. Journal of Phytopathology 146: 445-449.

Georgi, L.L., Y. Wang, D. Yvergiaux, T. Ormsbee, M. Iñigo, G. Reighard, and A.G. Abbott. 2002. Construction of a BAC library and its application to the identification of simple sequence repeats in peach [Prunus persica $(\mathrm{L})$ Batsch]. Theoretical and Applied Genetics 105: 1151-1158.

Gradziel, T.M., P. Martínez-Gómez, and A.M. Dandekar. 2001b. The use of S-allele specific PCR analysis to improve breeding efficiency for self-fertility in almond. HortScience 36: 440-440.

Gradziel, T.M., D.E. Kester, and P. MartínezGómez. 2002. A development based classification for branch architecture in almond. Journal of the American Pomological Society 56: 106-112.

Gradziel, T.M., P. Martínez-Gómez, F. Dicenta, and D.E. Kester. 2001a. The utilization of related almond species for almond variety improvement. Journal of the American 
Pomological Society 55: 100-109. Grasselly, C. 1976. Les espèces sauvages d'amandier. Options Méditerranéennes. 32: 28-44. Gulcan, R. 1975. Cytological studies on young seedlings of double almond seeds. p. 15-17. In: II Colloque du Groupe de Recherche et d'ètude Mediterranéen pour l'Amandier, Montpellier, France.

Gupta, P.K., H.S. Balyan, P.C. Sharma, and B. Ramesh. 1996. Microsatellites in plants: a new class of molecular markers. Current Science 70: 45-54.

Hammerschlag, F.A. 1986. Temperate fruits and nuts. p. 121-236. In: R.H. Zimmerman, R.J. Griesbach, F.A. Hammerschlag, and R.H. Lawson (ed.) Tissue Culture as a Plant Production System for Horticultural Crops. Martinus Nijhoff Publishers, The Netherlands. Hammerschlag, F.A., and A.C. Smigocki. 1998. Growth and in vitro propagation of peach plants transformed with the shooty mutant strain of Agrobacterium tumefaciens. HortScience 33: 897-899.

Hartman, H.T., and D.E. Kester. 1959. Plant Propagation. Principles and Practices. Prentice Hall Inc. Englewood Cliffs, New Jersey, USA. 662 pp.

Hauagge, R., D.E. Kester, and R.A. Asay. 1987. Isozyme variation among California almond cultivars: I. Inheritance. Journal of the American Society for Horticultural Science 112: 687-693.

Hesse, C.O. 1971. Monoploid peaches, Prunus persica Batsch: Description and meiotic analysis. Journal of the American Society for Horticultural Science 96: 326-330.

Hesse, C.O. 1975. Peaches. p. 285-326. In: J. Janick, and J.N. Moore. (eds.) Advances in Fruit Breeding. Purdue University Press, West Lafayette, Indiana, USA.

Hormaza, J.I. 2002. Molecular characterization and similarity relationships among apricot genotypes using simple sequence repeats. Theoretical and Applied Genetics 104: 321-328.

Howad, W., and P. Arús. 2004. Mapeo selectivo o cómo situar marcadores en un mapa con muy pocas plantas. II Congreso de Mejora Genética de Plantas. León, Spain. Actas de Horticultura 41: 225-227.

Hurtado, M.A., C. Romero, S. Vilanova, A.G. Abbott, G. Llácer, and M.L. Badenes. 2002a. Genetic diversity in apricot cultivars based on AFLP markers. Euphytica 127: 297-301. Hurtado, M.A., C. Romero, S. Vilanova, A.G. Abbott, G. Llácer, and M.L. Badenes. 2002b. Genetic linkage maps of two apricot cultivars (Prunus armeniaca L.), and mapping of PPV (sharka) resistance. Theoretical and Applied Genetics 105: 182-191.

Hutchinson, J.F. 1987. Tissue culture of temperate fruit and nut trees. Horticultural Reviews 9: 273-350.

Jarausch, W., M. Lansac, C. Portanier, D.L. Davies, and V. Decroocq. 2000. In vitro grafting: a new tool to transmit pome fruit phytoplasmas to non-natural fruit tree hosts. Advances in Horticultural Science 14: 29-32.

Jauregui, B., M.C. de Vicente, R. Messeguer, A. Felipe, A. Bonnet, G. Salesses, and P. Arús. 2001. A reciprocal translocation between 'Garfi' almond and 'Nemared' peach. Theoretical and Applied Genetics 102: 1169-1176.

Jonard, R. 1986. Micrografting and its application to tree improvement. Biotechnology in Agriculture and Forestry 2: 31-48. Joobeur, T., N. Periam, M.C. de Vicente, G.J. King, and P. Arús. 2000. Development of a second generation linkage map for almond using RAPD and SSR markers. Genome 43: 649-655. Joobeur, T., M.A. Viruel, M.C. de Vicente, B. Jáuregui, J. Ballester, M.T. Dettori, I. Verde, M.J. Truco, R. Messeguer, I. Battle, R. Quarta, E. Dirlewanger, and P. Arús. 1998. Construction of a saturated linkage map for Prunus using an almond $x$ peach $\mathrm{F} 2$ progeny. Theoretical and Applied Genetics 97: 1034-1041.

Jun, J.H., K.H. Chung, S.B. Jeong, and H.J. Lee. 2002. Development of RAPD and SCAR markers linked to flesh adhesion gene in peach. XXVI International Horticultural Congress. Toronto, Canada, August 11-17, 2002. p. 335. Kester, D.E., and T.M. Gradziel. 1996. Almonds. p. 1-97. In: J.N. Moore, and J. Janick (eds.) Fruit Breeding. John Wiley \& Sons, New York, USA. 
Kester, D.E., T.M. Gradziel, and C. Grasselly. 1991. Almonds (Prunus). In: J.N. Moore, and H.J. Ballington Jr. (ed.) Genetic Resources of Temperate Fruit and Nut Crops. Acta Horticulturae 209: 701-758.

Kester, D.E., T.M. Gradziel, P. Martínez-Gómez, L. Liu, and K. Pelletreau. 2003. Evidence for two seasonal dormancies (paradormancy and endodormancy) in vegetative buds of almond (Prunus dulcis). HortScience 38: 740.

Kester, D.E., and C.J. Hansen. 1966. Rootstock potentialities of F1 hybrids between peach (Prunus persica L.) and almond (Prunus amygdalus Batsch.). Journal of the American Society for Horticultural Science 89: 100-109.

Knapp, S.J. 1998. Marker-assisted selection as a strategy for increasing the probability of selecting superior genotypes. Crop Science 38: 1164-1174.

Lazzari, B., A. Caprera, A. Vecchietti, F. Bianchi, L. Milanesi, A. Stella, and C. Pozzi. 2004. ESTree DB: a bioinformatic tool for peach functional genomics. International Rosaceae Genome Mapping Conference. www.genome.clemson.edu/gdr/conference/ program.html. Clemsom, USA.

Lecouls, A.C., M.J. Rubio, J.C. Cabetas, J.C. Minot, R. Voisin, A. Bonnet, G. Salesses, E. Dirlewanger, and D. Esmenjaud. 1999. RAPD and SCAR markers linked to the Ma1 rootknot nematode resistance gene in Myrobalan plum (Prunus cerasifera Ehr.). Theoretical and Applied Genetics 99: 328-335.

Lee, S., and J. Wen. 2001. A phylogenetic analysis of Prunus and the Amygdaloideae (Rosaceae) using ITS sequences of nuclear ribosomal DNA. American Journal of Botany 88: 150-160.

Lu, Z.X., G.L. Reighard, W.V. Baird, A.G. Abbott, and S. Rajapakse. 1996. Identification of peach rootstock cultivars by RAPD markers. HortScience 31: 127-129.

Lu, Z.X., B. Sosinski, G.L. Reighard, W.V. Baird, and A.G. Abbott. 1998. Construction of a genetic linkage map and identification of AFLP markers for resistance to root-knot nematodes in peach rootstocks. Genome 41: 199-207. Lu, Z.X., K. Sossey-Alaoui, G.L. Reighard, W.V.
Baird, and A.G. Abbott. 1999. Development and characterization of a codominant marker linked to root-knot nematode resistance, and its application to peach breeding. Theoretical and Applied Genetics 99: 115-122.

Luby J.J., and D.V. Shaw. 2001. Does markerassisted selection make dollars and sense in a fruit breeding program?. HortScience 36: 872-879.

Mante, S., U. Cornell, P. Morgens, R. Scorza, J. Cordts, and A. Callahan. 1990. Agrobacterium-mediated transformation of plum (Prunus domestica L.) hypocotyl segments and regeneration of transgenic plants. In Vitro 26: 44.

Mante, S., P.H. Morgens, R. Scorza, J.M. Cordts, and A.M. Callahan. 1991. Agrobacteriummediated transformation of plum (Prunus domestica L.) hypocotyl slices and regeneration of transgenic plants. Biotechnology 9: 853-857.

Marcotrigiano, M., and T.M. Gradziel. 1997. Genetic mosaics and plant improvement. Plant Breeding Reviews 15: 43-84.

Martínez-Gómez, P., S. Arulsekar, D. Potter, and T.M. Gradziel. 2003a. An extended interspecific gene pool available to peach and almond breeding as characterized using simple sequence repeat (SSR) markers. Euphytica 131: 313-322.

Martínez-Gómez, P., S. Arulsekar, D. Potter, and T.M. Gradziel. 2003b. Relationships among peach and almond and related species as detected by SSR markers. Journal of the American Society for Horticultural Science 128: 667-671.

Martínez-Gómez, P., and F. Dicenta. 2000. In vitro evaluation of apricot resistance to plum pox potyvirus. Journal of Horticultural Science \& Biotechnology 75: 259-261.

Martínez-Gómez, P., F. Dicenta, and J.M. Audergon. 2000a. Behaviour of apricot (Prunus armeniaca L.) cultivars in the presence of sharka (Plum pox potyvirus): a review. Agronomie 20: 407-422.

Martínez-Gómez, P., F. Dicenta, and J. Egea. 2000b. Breaking dormancy of GF305 peach and Real Fino apricot trees during the evaluation of 
resistance to sharka (Plum pox potyvirus). Agronomie 20: 885-892.

Martínez-Gómez, P., and T.M. Gradziel. 2001a. In-vivo micrograft in almond and their applications in breeding programs. HortTechnology 11: 313-315.

Martínez-Gómez, P., and T.M. Gradziel. 2001b. Rescue of aneuploids in 'Nonpareil' almond by in-vivo micrografts. HortScience 36: 536-536.

Martínez-Gómez, P., and T.M. Gradziel. 2003. Sexual polyembryony in almond. Sexual Plant Reproduction 16: 135-139.

Martins, M., R. Tenreiro, and M.M. Oliveira. 2003. Genetic relatedness of Portuguese almond cultivars assessed by RAPD and ISSR markers. Plant Cell Reports 22: 71-78.

McCord, P., T. Zhebentyayeva, A. Abbott, and B. Sosinski. 2004. Fabrication of first-generation Prunus microarray and its use in expression profiling of peach development. International Rosaceae Genome Mapping Conference. www.genome.clemson.edu/gdr/conference/ program.html. (accessed May 2005). Clemsom, USA.

Mehlenbacher, S.A. 1995. Classical and molecular approaches to breeding fruit and nut crops for disease resistance. HortScience 30: 466-477.

Michelmore, R.W., I. Paran, and R.V. Kesseli. 1991. Identification of markers linked to disease resistance genes by bulk segregant analysis. A rapid method to detect markers in specific genomic regions by using segregating populations. Proceedings of the National Academy of Sciences of the United States of America 88: 9828-9832.

Miguel, C.M., and M.M. Oliveira. 1999. Transgenic almond (Prunus dulcis Mill.) plants obtained by Agrobacterium-mediated transformation of leaf explants. Plant Cell Reports 18: 387-393.

MirAli, N., and I. Nabulsi. 2003. Genetic diversity of almonds (Prunus dulcis) using RAPD technique. Scientia Horticulturae 98: 461-471.

Mora-Aguilera, G., L. Levy, D. Teliz, P. MartínezGómez, F. Dicenta, R. Nieto-Angel, and A. Gutiérrez-Espinosa. 1998. Plum pox virus: A potential quarantine pest of Mexico. Rev. Chapingo 5: 55-62.
Mowrey, B.D., and D.J. Werner. 1990. Phylogenetic relationships among species of Prunus as inferred by isoenzyme markers. Theoretical and Applied Genetics 80: 129-133.

Mowrey, B.D., D.J. Werner, and D.H. Byrne. 1990. Inheritance of isocitrate dehydrogenase, malate dehydrogenase, and shikimate dehydrogenase in peach and peach $\mathrm{x}$ almond hybrids. Journal of the American Society for Horticultural Science 115: 312-319.

Muehlbauer, G.J., J.E. Specht, M.A. ThomasCompton, P.E. Staswick, and R.L. Bernard. 1988. Near-isogenic lines, a potential resource in the integration of conventional and molecular marker linkage maps. Crop Science 28: 729-735.

Navarro, L., G. Llácer, M. Cambra, M. Arregui, and J. Juárez. 1982. Shoot-tip grafting in vitro for elimination of viruses in peach plants (Prunus persica, Batsch). Acta Horticulturae 130: 185-192.

Negueroles J., and O.P. Jones. 1979. Production in vitro of rootstock/scion combinations of Prunus cultivars. Journal of Horticultural Science 54: 279-281.

Olson, M., L. Hood, C. Cantor, and D. Botstein. 1989. A common language for physical mapping of the human genome. Science 245: 1434-1435.

Ortega, E., and F. Dicenta. 2003. Inheritance of self-compatibility in almond: breeding strategies to assure self-compatibility in the progeny. Theoretical and Applied Genetics 106: 904-911.

Paran, I., and R.W. Michelmore. 1993. Development of reliable PCR-based markers linked to downy mildew resistance genes in lettuce. Theoretical and Applied Genetics 85: 985-993.

Pascal, T., F. Pfeiffer, and J. Kervella. 2001. Preliminary observations on resistance to sharka in peach and related species. V International Peach Symposium. Davis, California, USA. p. 15.

Paunovic, S.A. 1988. Apricot germplasm, breeding, selection, cultivar, rootstock, and environmental. Acta Horticulturae 209: 13-28. 
Pedryc, A., J. Korbuly, and Z. Szabo. 1999. Artificial frost treatment methods of stone fruits. Acta Horticulturae 488: 377-380. Pérez-Tornero, O., L. Burgos, and J. Egea. 1999. Introduction and establishment of apricot in vitro through regeneration of shoots from meristem tips. In Vitro Cellular \& Developmental Biology-Plant 35: 249-253. Petri, C., and L. Burgos. 2005. Transformation of fruit trees. Useful breeding tool or continued future prospect?. Transgenic Research 14: 15-26.

Powell, W., M. Morgante, C. Andre, M. Hanafey, J. Vogel, S. Tingey, and A. Rafalski. 1996. Comparison of RFLP, RAPD, AFLP and SSR (microsatellite) markers for germplasm analysis. Molecular Breeding 2: 225-238.

Quarta, R., M.T. Dettori, A. Sartori, and I. Verde. 2000. Genetic linkage map and QTL analysis in peach. Acta Horticulturae 521: 233-241. Rajapakse, S., L.E. Belthoff, G. He, A.E. Estager, R. Scorza, I. Verde, R.E. Ballard, W.V. Baird, A. Callahan, R. Monet, and A.G. Abbott. 1995. Genetic linkage mapping in peach using morphological, RFLP and RAPD markers. Theoretical and Applied Genetics 90: 503-510.

Ravelonandro, M., R. Scorza, J.C. Bachelier, G. Labonne, L. Levy, V. Damsteegt, A.M. Callahan, and D. Dunez. 1997. Resistance of transgenic Prunus domestica to plum pox virus infection. Plant Disease 81: 1231-1235. Salava, J., Y. Wang, B. Kryska, J. Polak, P. Kominek, W. Miller, W.M. Dowler, G.L. Reighard, and A.G. Abbott. 2001. Identification of molecular markers linked to resistance of apricot (Prunus armeniaca L.) to plum pox virus. www.intl-pag.org. Plant \& Animal Genome IX Conference. San Diego, USA. Salesses, G., E. Dirlewanger, D. Esmenjaud, and A.C. Lecouls. 1998. Root knot nematode resistance in Myrobalan plum: inheritance and rootstock breeding perspectives using marker-assisted selection. Acta Horticulturae 478: 45-52.

Sánchez-Pérez, R., F. Dicenta, and P. MartínezGómez. 2004. Identification of S-alleles in almond using multiplex-PCR. Euphytica 138: 263-269.

Sánchez-Pérez, R., D. Ruiz, F. Dicenta, J. Egea, and P. Martínez-Gómez. 2005. Application of simple sequence repeat (SSR) markers in apricot breeding: molecular characterization, protection, and genetic relationships. Scientia Horticulturae 103: 305-315.

Sathe, S.K., S.S. Teuber, T.M. Gradziel, and K.H. Roux. 2001. Electrophoretic and immunological analyses of almond (Prunus dulcis L.) genotypes and hybrids. Journal of Agricultural and Food Chemistry 49: 2043-2052.

Schueler, S., A. Tusch, M. Schuster, and B. Ziegenhagen. 2003. Characterization of microsatellites in wild and sweet cherry markers for individual identification and reproductive processes. Genome 46: 95-102.

Scorza, R. 2001. Progress in tree fruit improvement through molecular genetics. HortScience 36: 855-857.

Scorza, R., A.M. Callahan, L. Levy, V. Damsteegt, and M. Ravelonandro. 1998. Transferring potyvirus coat protein genes through hybridization of transgenic plants to produce plum pox virus resistant plums (Prunus domestica L.). Acta Horticulturae 472: 421-427.

Scorza, R., S.A. Mehlenbacher, and G.W. Lightner. 1985. Inbreeding and coancestry of freestone peach cultivars of the eastern United States and implications for peach germplasm improvement. Journal of the American Society for Horticultural Science 110: 547-552. Scorza, R., P.H. Morgens, J.M. Cordts, S. Mante, and A.M. Callahan. 1990. Agrobacteriummediated transformation of peach (Prunus persica L. Batsch.) leaf segments, immature embryos, and long-term embryogenic callus. In Vitro Cellular \& Developmental BiologyPlant 26: 829-834.

Scorza, R., and M. Ravelonandro. 2002. Gene silencing-based resistance to plum pox virus. Acta Horticulturae 622: 119-122.

Scorza, R., and W.B. Sherman. 1996. Peaches. p. 203-268. In: J.N. Moore, and J. Janick (eds.) Fruit Breeding. John Wiley \& Sons, 
New York, USA.

Scorza, R., M. Ravelonandro, A.M. Collahan, M. Coralts, J. Dunez, and D. Gonsalves. 1994. Transgenic plum (Prunus domestica L.) expressing the plum pox virus coat protein gene. Plant Cell Reports 14: 18-24.

Serrano, B., J. Gómez-Aparisi, and J.I. Hormaza. 2002. Molecular fingerprinting of Prunus rootstock using SSRs. Journal of Horticultural Science \& Biotechnology 77: 368-372.

Singh, Z. 2000. Biotechnology in fruit crop improvement. p. 248-285. In: K.L. Chadha, P.N. Ravindran, and L. Sahijram. K.L. Chadha (eds.) Biotechnology in Horticultural and Plantation Crops. Publishers: Malhotra Publishing House, New Delhi, India. Singh, Z., and S. Sansavini. 1998. Genetic transformation and fruit crop improvement. Plant Breeding Reviews 16: 87-134. Smigocki, A.C., and F.A. Hammerschlag. 1991. Regeneration of plants from peach embryo cell infected with a shoddy mutant strain of Agrobacterium. Journal of the American Society for Horticultural Science 116: 1092-1097. Smith, B.R. 2002. Interspecific hybridization in Prunus: Accomplishments, barriers, and potential. XXVI International Horticultural Congress. Toronto, Canada, August 11-17, 2002. p. 329.

Sonneveld, T., T.P. Robbins, R. Bošković, and K.R. Tobutt. 2001. Cloning of six cherry selfincompatibility alleles and development of allele-specific PCR detection. Theoretical and Applied Genetics 102: 1046-1055. Sonneveld, T., K.R. Tobutt, and T.P. Robbins. 2003. Allele-specific PCR detection of sweet cherry self-incompatibility alleles S1 to S16 using consensus and allele-specific primers. Theoretical and Applied Genetics 107: 1059-1070.

Sosinski, B., M. Gannavarapu, L.E. Hager, L.E. Beck, G.J. King, C.D. Ryder, S. Rajapakse, W.V. Baird, R.E. Ballard, and A.G. Abbott. 2000. Characterization of microsatellite markers in peach (Prunus persica (L) Batsch). Theoretical and Applied Genetics 101: 421-428.
Sosinski, B., Z.X. Lu, A. Tabb, K. Sossey-Alaoui, S. Rajapakse, K. Glassmoyer, R. Scorza, G. Reighard, R.E. Ballard, W.V. Baird, and A.G. Abbott. 1998. Use of AFLP and RFLP markers to create a combined linkage map in peach [Prunus persica (L.) Batsch] for use in marker assisted selection. Acta Horticulturae 465: 61-68.

Stockinger, E.J., C.A. Mulinix, C.M. Long, T.S. Brettin, and A.F. Iezzoni. 1996. A linkage map of sweet cherry based on RAPD analysis of a microspore-derived callus culture population. Journal of Heredity 87: 214-218.

Struss, D., R. Ahmad, S.M. Southwick, and M. Boritzki. 2003. Analysis of sweet cherry (Prunus avium L.) cultivars using SSR and AFLP. Journal of the American Society for Horticultural Science 128: 904-909. Tamura, M., K. Ushijima, H. Sassa, H. Hirano, R. Tao, T.M. Gradziel, and A.M. Dandekar. 2000. Identification of self-incompatibility genotypes of almond by allele-specific PCR analysis. Theoretical and Applied Genetics 101: 344-349.

Tanksley, S.D., N.D. Young, A.H. Patterson, and M.W. Bonierbale. 1989. RFLP mapping in plant breeding: New tools for an old science. Biotechnology 7: 257-264.

Tao, R., T. Habu, H. Yamane, A. Sugiura, and K. Iwamoto. 2000. Molecular markers for selfcompatibility in Japanese apricot (Prunus mume). HortScience 35: 1121-1123.

Tao, R., H. Yamane, H. Sassa, H. Mori, T.M. Gradziel, A.M. Dandekar, and A. Sugiura. 1997. Identification of stylar RNases associated with gametophytic self-incompatibility in almond (Prunus dulcis). Plant and Cell Physiology 38: 304-311.

Testolin, R. 2003. Marker assisted selection (MAS) in stone fruits. Acta Horticulturae 633: 163-176.

Testolin, R., T. Marrazzo, G. Cipriani, R. Quarta, I. Verde, T. Dettori, M. Pancaldi, and S. Sansavini. 2000. Microsatellite DNA in peach (Prunus persica (L.) Batsch) and its use in fingerprinting and testing the genetic origin of cultivars. Genome 43: 512-520. 
Van Nocker, S., A. Sebolt, and A. Iezzoni. 2002. SSR markers for Prunus developed from a small EST data set. XXVI International Horticultural Congress. Toronto, Canada, August 11-17, 2002. p. 332.

Verde, I., R. Quarta, C. Cedrola, and M.T. Dettori. 2002. QTL analysis of agronomic traits in a BC1 peach population. Acta Horticulturae 592: 291-297.

Vilanova, S., C. Romero, A.G. Abbott, G. Llácer, and M.L. Badenes. 2003. An apricot (Prunus armeniaca L.) F2 progeny linkage map based on SSR and AFLP markers, mapping plum pox virus resistance and self-incompatibility traits. Theoretical and Applied Genetics 107: 239-247.

Viruel, M.A., D. Madur, E. Dirlewanger, T. Pacasl, and J. Kervella. 1998. Mapping quantitative trait loci controlling peach leaf curl resistance. Acta Horticulturae 465: 79-87.

Viruel, M.A., R. Messeguer, M.C. de Vicente, J. García-Mas, P. Puigdomènech, F. Vargas, and P. Arús. 1995. A linkage map with RFLP and isozyme markers for almond. Theoretical and Applied Genetics 91: 964-971.

Vlasic, A. 1977. L'Amygdalus webbi Spach ed I suolsi ibridi col pesco com portaninnestro del mandorlo. 3d Colloque GREMPA. Bari, Italy. p. $80-81$.

Vos, P., R. Hogers, M. Bleeker, M. Reijans, T. Lee, M. Hornes, A. Frijters, J. Pot, J. Peleman, M. Kuiper, and M. Zabeau. 1995. AFLP: a new technique for DNA fingerprinting. Nucleic Acids Research 23: 4407-4414.

Wang, Y., L.L. Georgi, N. Zhebentyayeva, G.L. Reighard, R. Scorza, and A.G. Abbott. 2002. High throughput targeted SSR marker development in peach (Prunus persica). Genome 45: 319-328.

Wang, D., R. Karle, and A.F. Iezzoni. 2000. QTL analysis of flower and fruit traits in sour cherry. Theoretical and Applied Genetics 100: 535-544.

Warburton, M.L., V.L. Becerra-Velásquez, J.C. Goffreda, and F.A. Bliss. 1996. Utility of RAPD markers in identifying genetic linkages to genes of economic interest in peach.
Theoretical and Applied Genetics 93: 920-925. Warburton, M.L., and F.A. Bliss. 1996. Genetic diversity in peach (Prunus persica L. Batch) revealed by randomly amplified polymorphic DNA (RAPD) markers and compared to inbreeding coefficients. Journal of the American Society for Horticultural Science 121: 1012-1019.

Weeden, N.F. 1994. Approaches to mapping in horticultural crops. p. 57-68. In: P.M. Gresshoff (ed.) Plant Genome Analysis. CRC Press, Boca Raton, Florida, USA.

Welsh, J., and M. McClelland. 1990. Fingerprinting genomes using PCR with arbitrary primers. Nucleic Acids Research 18: 7213-7218.

Wenzel, G., and B. Foroughi-Wehr. 1993. In vitro selection. p. 353-371. In: M.D. Hayward, N.O. Bosemark, and I. Romagosa (eds.) Plant Breeding: Principles and Prospects. Chapman \& Hall, London, United Kingdom.

Wünsch, A., and J.I. Hormaza. 2002a. Cultivar identification and genetic fingerprinting of temperate fruit tree species using DNA markers. Euphytica 125: 56-67.

Wünsch, A., and J.I. Hormaza. 2002b. Molecular characterisation of sweet cherry (Prunus avium L.) genotypes using peach (Prunus persica L.) SSR sequences. Heredity 89: 56-63.

Xiaojian, Y., S.K. Brown, R. Scorza, J. Cordts, and J.C. Sanford. 1994. Genetic transformation of peach tissue by particle bombardment. Journal of the American Society for Horticultural Science 119: 367-373. Yaegaki, H., T. Shimada, T. Moriguchi, H. Hayama, T. Haji, and M. Yamaguchi. 2001. Molecular characterization of S-RNase genes and Sgenotypes in the Japanese apricot (Prunus mume Sieb. et Zucc.). Sexual Plant Reproduction 13: 251-257.

Yamamoto, T., and T. Hayashi. 2002. New rootknot nematode resistance genes and their STS markers in peach. Scientia Horticulturae 96: 81-90.

Yamamoto, T., K. Mochida, T. Imai, I.Z. Shi, I. Ogiwara, and T. Hayashi. 2002. Microsatellite markers in peach [Prunus persica (L.) Batsch] derived from an enriched genomic and cDNA 
libraries. Molecular Ecology Notes 2: 298-302. Yamamoto, T., T. Shimada, T. Imai, T. Yaegaki, T. Haji, N. Matsuta, M. Yamaguchi and T. Hayashi. 2001. Characterization of morphological traits based on a genetic linkage map in peach. Breeding Science 51: 271-278. Young, N.D., D. Zamir, M.W. Ganal, and S.D. Tanksley. 1988. Use of isogenic lines and simultaneous probing to identify DNA markers tightly linked to the Tm-2a gene in tomato. Genetics 120: 579-585.

Zhebentyayeva, T.N., G.L. Reighard, V.M. Gorina, and A.G. Abbott. 2003. Microstellite (SSR) analysis for assessment of genetic variability in apricot germplasm. Theoretical and Applied Genetics 106: 435-444. 